chemical characterisation; it is present in such minute quantities in the jelly and probably contaminated by other substances diffusing from the injured cells. It has been impossible to produce similar activity by the use of any pure substance in its place.

A new chapter thus seems to be opened in the study of the correlating influences controlling the process of cell extension in the tissues of the plant. It is safe to predict that the subject will not be left long in this interesting state, but that further work will elucidate the connexion of the apex of the coleoptile with the extension of its base, and at the same time determine the significance of this mysterious Wuchsstoff that diffuses from the cut tip when placed on agar.
J. H. P.

\title{
The Wright Brothers' and Langley's Aeroplanes.
}

$\mathrm{I}^{\mathrm{N}}$ $\mathrm{N}$ the new wing of the Science Museum, South Kensington, in perhaps the most prominent position, will be found the original Wright aeroplane with a long descriptive notice. This states that it was the first power-driven man-carrying aeroplane to make a free, controlled, and sustained flight. The machine, which was built by Wilbur and Orville Wright, was flown by them on Dec. 17, 1903, at Kittyhawk, North Carolina, and its production was the result of their prolonged experimentation and research, which had been stimulated by the gliding experiments of Otto Lilienthal.

Since the first flights were made the aeroplane has been preserved in the Wright laboratory, but certain parts which had been damaged during their last flight, one extending over 59 seconds and covering a distance of 852 feet, have been replaced, and the machine restored to its original condition.

The fact that this machine, essentially American in ownership and manufacture, should be in the possession of a British museum is rather significant, and is the key to a publication which has just been issued by the Smithsonian Institution, dealing with their relations with the Wright Brothers. The publication, which was issued over the name of C. G. Abbot, Secretary of the Institution, is an attempt to clarify an unfortunate controversy, to correct misunderstandings, and to do justice alike to three great pioneers of human flight--Wilbur and Orville Wright, and Samuel Pierpoint Langley, who, as they themselves said, gave them "a helping hand at a critical time." The details of the controversy, which in parts is rather painful, need not concern us at present, but the difficulty was associated with the exhibition in the United States National Museum in 1918 of a reconstructed variation of a machine which Langley endeavoured to fly in 1903. The label attached to it originally described it as "The original full-sized Langley Flying Machine"; this was later amplified to include a claim that it was the first man-carrying aeroplane in the history of the world capable of sustained free flight; that it was tested over the

Potomac River by Langley in 1903, and successfully flown in June 1914.

As a result of the controversy and further investigation into the actual flights carried through by this machine, the label was altered to indicate that in the opinion of " many competent to judge," the machine was the first " heavier than air craft", in the history of the world capable of free flight under its own power, since it had become clear that in the original test no proper flight had emerged. Smarting under a sense of injustice, Mr. Orville Wright presented their machine for exhibition for five years to the South Kensington Museum.

Committees connected with the Smithsonian Institution have investigated the historical accuracy of the statements which have appeared on the labels, and now in this pamphlet the invitation of the Smithsonian Institution to Mr. Wright is renewed, to deposit for perpetual preservation in the United States National Museum the Kittyhawk plane with which he and his brother, it is agreed, were the first in history to make successful sustained human flight in a power-propelled heavier-than-air machine.

As a further display of goodwill, the Institution is willing to let Langley's aeroplane rest on its merits, and has directed that the label on the Langley Aerodrome shall be so modified as to tell nothing but facts, without additions of opinion as to the accomplishments of Langley. The label now reads: "Langley Aerodrome. The original Samuel Pierpoint Langley Flying Machine of 1903. Restored.'

No doubt it was because the Wright brothers have always been appreciated in Great Britain for their wonderful pioneer work in this new field of human endeavour that the machine was deposited in one of our Museums. Whether or no it should now be returned to the United States is clearly a matter for Mr. Orville Wright himself to decide. We, at any rate, in Great Britain shall be extremely sorry if it is to leave our shores; but in any case it is to be hoped that the Science Museum authorities will take steps to procure the production of as close a replica as possible.

\section{Obituary.}

\section{Prof. T. C. Chamberlin.}

\section{A} MASTER of research has passed in Thomas Crowder Chamberlin, emeritus professor of geology in the University of Chicago, whose death occurred on Nov. 15, shortly after celebrating his eighty-fifth birthday on Sept. 25. His place is with the greatest thinkers of the past. He leaves few if any equals among his contemporaries. His farflung research into the processes of the universe is a challenge to younger students to spread wings of imagination toward the unknown, but only with thorough understanding of the course to be flown and constant checking of the navigation.

Chamberlin, the glacialist, geophysicist, and cos-

No. 3085, VoL. 122] 